\title{
Lymphocyte subpopulations in the equine endometrium: a methodical approach with diagnostic implications
}

\author{
Nicole Huth 7 , Sandra Schöniger ${ }^{7}$, Harald Sieme², Claus-Peter Bartmann³, Heinz-Adolf Schoon \\ ${ }^{1}$ Institute of Pathology, Faculty of Veterinary Medicine, University of Leipzig, Germany \\ ${ }^{2}$ Clinic for Horses - Unit for Reproductive Medicine, University of Veterinary Medicine, Hannover, Germany \\ 3 Bad Reichenhall, Germany
}

\begin{abstract}
Summary
In the equine endometrium, the subclassification of lymphocytes may provide further insights into the immune defense and the pathogenesis of a non-suppurative endometritis. In routine formalin-fixed paraffin embedded tissue, there is no preservation of CD4 and CD8 antigens of T-helper cells and cytotoxic T cells, respectively. So far, the immunohistochemical detection of CD4- and CD8-immunopositive lymphocytes in the equine endometrium was only achieved by the use of frozen cryostat sectioned tissue samples. The aim of the present study on the equine endometrium was 1) to explore alternative fixation methods for the immunohistochemical detection of CD4 and CD8 antigens, 2) to reveal the method most suitable for the routine diagnostic work-up in conjunction with an immunohistochemical characterization of lymphocyte subpopulations and 3) to examine the distribution of CD4- and CD8-immunopositive lymphocytes in the equine endometrium without and with a non-suppurative endometritis. Using the zinc-salt and the Hope ${ }^{\circledR}$-fixative as alternative fixatives, the immunohistochemical detection of CD4- and CD8-immunopositive lymphocytes was possible. In haemalaun eosin stained tissue sections, however, only zinc-salt fixed tissue had an optimal tissue morphology comparable to the tissue preservation in formalin-fixed tissue. The immunohistochemical examination of endometrial tissue samples of 2 mares without endometritis and 7 mares with a mild superficial non-suppurative endometritis showed the presence of CD4- and CD8-immunopositive subpopulations within the stratum compactum and stratum spongiosum. The mild non-suppurative endometritis was associated with increased numbers of CD4- and CD8-immunopositive lymphocytes within the stratum compactum. This study on the equine endometrium shows that 1) CD4-and CD8-immunopositive T cell subpopulations can also be detected in fixed tissue samples (IHC Zinc Fixative and Hope ${ }^{\circledR}$-fixation), 2) the IHC Zinc Fixative is an excellent method to combine the routine histopathological evaluation with the analysis of T cell subpopulations, 3) the equine endometrium is equipped with an adaptive immune defense acting against intracellular and extracellular pathogens, 4) a non-suppurative endometritis is associated with an increase in both cell populations indicative of an immune mediated pathogenesis. Further studies are necessary to characterise the lymphocyte populations in the equine endometrium and the described method will provide a powerful diagnostic tool.
\end{abstract}

Keywords: CD4 antigen / CD8 antigen / endometritis / mare / T lymphocyte subpopulations / zinc-salt fixative / reproduction

Correspondence: Dr. Nicole Huth, University of Leipzig, Faculty of Veterinary Medicine, Institute of Pathology, An den Tierkliniken 33, 04103 Leipzig, Germany. E-Mail: nicole.huth@vetmed.uni-leipzig.de

Citation: Huth N., Schöniger S., Sieme H., Bartmann C.-P., Schoon H.-A. (2014) Lymphocyte subpopulations in the equine endometrium: a methodical approach with diagnostic implications. Pferdeheilkunde 30, 4-14

\section{Introduction}

In the equine endometrium, the subclassification of mononuclear cells may provide answers for the immune defense of the healthy endometrium and the pathogenesis of subclinical endometrial inflammatory lesions, in particular those associated with a non-suppurative inflammation. The latter is mediated by mononuclear inflammatory cells (macrophages, lymphocytes and/or plasma cells).

In equine reproductive medicine, the diagnosis and treatment of a non-suppurative endometritis is often problematic. Affected mares usually do not show other clinical signs than barrenness (LeBlanc and Causey 2009) consistent with a subclinical endometritis. The only diagnostic test that will definitively reveal a subclinical endometritis, is the histopathological examination of an endometrial biopsy (LeBlanc and Causey 2009) using the criteria defined by Kenney and Doig (1986) and Schoon et al. (1992) and (1997). This type of endometritis is commonly not associated with a positive bacterial culture (Schoon et al. 1997). Besides an infectious etiology, endometrial inflammation may be sterile, associated with an allergic-hyperergic reaction or the persistence of anti- gens (Schoon et al. 1992). Since the cause of a non-suppurative endometritis is often uncertain, specific therapeutic options are not available.

T lymphocytes defend intra- and extracellular pathogens and also recognize 'foreign material' and 'foreign cells' (Kidd 2003, Murphy et al. 2009). Two main subclasses exist, i. e. either CD4- or CD8-immunopositive (+) T cells. Cytotoxic $(C D 8+) \mathrm{T}$ cells are activated by antigens of intracellular cytosolic pathogens (for example viruses, bacteria); they will kill their target cells by apoptosis. Effector CD4+ cells include T-helper cells (TH1 and $\mathrm{TH} 2$ cells), regulatory $\mathrm{T}$ cells (Tregs) and TH1 7 cells (Kidd 2003, Murphy et al. 2009). A simplified point of view shows that $\mathrm{TH} 1$ cells are mainly activated by macrophages presenting peptides of phagocytized intracellular pathogens and subsequently stimulate the cellular immune response. In contrast, B cells presenting peptides of extracellular antigens stimulate TH2 cells; this is followed by the initiation of a humoral immune response (Kidd 2003, Murphy et al. 2009). Treg cells downregulate exuberant $T$ cell responses (Burzyn et al. 2013). TH17 cells appear to modulate immune responses, and increased numbers of 
TH17 cells have been associated with autoimmunity (Sundrud and Trivigno 2013).

So far, the immunohistochemical detection of subpopulations of lymphocytes in the equine endometrium was only performed on cryostat sections of native tissue that were briefly $(5-10$ min) fixed in acetone prior to the immunohistochemical procedure (Watson and Thomson 1996, Tunón et al. 2000). The use of cryostat sections, however, is impractical for the routine histopathological examination of endometrial biopsies, since it requires freezing and specific transport conditions. To combine the routine diagnostic work-up with a concise analysis of the endometrial immune cell populations, there is a demand for an alternative fixative. In particular in human medicine, Hope $^{\circledR}$ (Olert et al. 2001) and zinc-salt fixatives (Beckstead 1994) have been used for the investigation of lymphocyte subpopulations.

The aim of the present study was 1) to test the immunohistochemical reactivity of antibodies for the subclassification of $T$ lymphocytes in fixed and paraffin embedded tissue samples using the alternative fixation methods Hope ${ }^{\circledR}$ and zinc-salt fixative, 2) to reveal the method most suitable for a routine diagnostic work up in conjunction with an immunohistochemical subclassification of T lymphocytes and 3) to characterize the $T$ lymphocyte subpopulations in the equine endometrium with and without a non-suppurative endometritis.

\section{Material and Methods}

Animals and endometrial tissue samples

To investigate the immunoreactivity of the primary antibodies for the detection of $\mathrm{T}$ cells including their subpopulations in tissue samples treated by different methods, endometrial tissue were obtained from 5 adult mares. These mares were euthanized due to other reasons than genital tract disease. Macroscopically, the genital tract of these mares did not show any significant findings. From each of these mares, endometrial tissue samples (up to $0.8 \times 0.8 \times 0.8 \mathrm{~cm}$ ) were collected immediately after their euthanasia. These tissue samples were either fixed in $10 \%$ neutral buffered formalin, Hope ${ }^{\circledR}$ fixative (DCS, Innovative Diagnostik-Systeme, Hamburg, Germany) or IHC Zinc Fixative (BD Biosciences Pharmingen, Heidelberg, Germany), or they were native snap frozen in liquid nitrogen, stored at $-80^{\circ} \mathrm{Celsius}(\mathrm{C})$ and subsequently cryostat sectioned.

The characterization of $T$ cell populations was performed in endometrial biopsies from 9 adult Thoroughbred mares and endometrial tissue samples from one 21 -year-old German riding pony. These tissue samples were also examined by histopathology. After their collection, endometrial biopsies were cut in halve, one portion was fixed in $10 \%$ buffered formalin, the other was placed in IHC Zinc Fixative. Endometrial tissue samples of the pony were fixed using either formalin or IHC Zinc Fixative. On microscopic examination, 2 Thoroughbred mares had no evidence of endometritis, and 7 showed a mild non-suppurative superficial endometritis. The pony was euthanized due to other reasons than genital disease, did not show any gross evidence of a geni- tal tract disease, and had microscopically a non-suppurative endometritis. The endometrial tissue samples of the euthanized mare were collected and processed immediately after euthanasia.

\section{Cryostat sectioning}

Frozen tissue specimens were embedded in O.C.T. compound (Engelbrecht Medizin- und Labortechnik GmbH, Edermünde, Germany) and sectioned $(7 \mu \mathrm{m})$ using the 2800 Frigocut E cryostat (Reichert-Jung, Cambridge Instruments $\mathrm{GmbH}$, Nussloch, Germany). Slices were mounted on SuperFrost/Plus slides (Menzel, Engelbrecht Medizin- und Labortechnik $\mathrm{GmbH}$, Edermünde, Germany), air-dried for 10 minutes $(\mathrm{min})$ at room temperature (RT), $10 \mathrm{~min}$ fixed in pure acetone at $-20^{\circ} \mathrm{C}$ and again air-dried for $10 \mathrm{~min}$ at RT. Subsequently, sections were stained with haemalaun and eosin (H.E., Merck KGaA, Darmstadt, Germany) or used for immunohistochemistry.

Fixation, paraffin-embedding of tissue samples and sectioning

Formalin fixation

Tissue samples were fixed in $10 \%$ buffered formalin for up to 48 hours (hrs), routinely processed by an automated tissue processor (Hypercenter XP, Shandon, Frankfurt/Main, Germany) that uses an ascending alcohol series for dehydration and paraffin immersion. The subsequent tissue embedding into paraffin wax (melting at $56-58^{\circ} \mathrm{C}$, Engelbrecht Medizin- und Labortechnik $\mathrm{GmbH}$, Edermünde, Germany) was performed manually using a tissue embedding station (TES 99, Medite Medizintechnik, Burgdorf, Germany). Paraffin blocks were stored at RT.

\section{IHC Zinc Fixative}

The zinc-salt fixation was performed according to the manufacturers' instructions. Tissue samples were fixed between $24 \mathrm{hrs}$ and $48 \mathrm{hrs}$, rinsed in tap water and processed in the automated tissue processor (Hypercenter XP, Shandon, Frankfurt/Main, Germany) by placing them directly into the ascending alcohol series. Tissues were finally embedded in paraffin wax (melting at $56-58^{\circ} \mathrm{C}$, Engelbrecht Medizin- und Labortechnik $\mathrm{GmbH}$ ). Storage of paraffin blocks was performed at RT.

Hope ${ }^{\circledR}$ fixation

For the Hope ${ }^{\circledR}$ fixation - applied according to the guidelines of the manufacturer - tissue samples were placed in ice-cold Hope ${ }^{\circledR}$ I solution (12 to $72 \mathrm{hrs}$ at $0-4^{\circ} \mathrm{C}$ ) and subsequently transferred into ice-cold Hope ${ }^{\circledR}$ II - acetone solution (2 hrs at $2{ }^{\circ} \mathrm{C}$ ). This was followed by tissue incubation in pure ice-cold acetone performed three times for $2 \mathrm{hrs}$ at $2^{\circ} \mathrm{C}$. After $8 \mathrm{hrs}$ of dehydration, low melting paraffin (DCS, Innovative Diagnostik-Systeme) was added to the tissue samples. These were incubated in paraffin over night at $54{ }^{\circ} \mathrm{C}$ and finally paraffin embedded. Paraffin blocks were stored at $4 \mathrm{C}^{\circ}$ until sectioning. Tissue sections $(2 \mu \mathrm{m})$ of paraffin-embedded fixed tis- 
sues (10\% buffered formalin, IHC Zinc Fixative, Hope ${ }^{\circledR}$ ) were cut using a microtome (Microm HM400, DiaTec Diagnostische System-Technik, Hallstadt, Germany), stained with HE or used for immunohistochemistry.

\section{Histopathology}

HE stained sections of formalin- and zinc-fixed endometrial tissue samples that were collected from the 9 Thoroughbred mares and the 21 -year-old German riding pony, were evaluated to determine the functional morphology of endometrial glands and to examine the presence of endometrial inflammatory and degenerative lesions using the diagnostic criteria provided by Kenney and Doig (1986) and Schoon et al. (1992) and (1997).

\section{Immunohistochemistry}

Tissue sections $(2 \mu \mathrm{m})$ were mounted on SuperFrost/Plus slides (Menzel, Engelbrecht Medizin- und Labortechnik GmbH) and air-dried. Primary antibodies were the polyclonal (pAb) pan-T cell marker CD3 (rabbit anti-human, Dako, Hamburg, Germany) and the monoclonal antibodies (mAb) detecting CD4 (clone: HB61A; Washington State University, Pullman, USA; Kydd et al. 1994) and CD8 (clone: HT14A, Washington State University, Pullman, USA; Kydd et al. 1994). Optimal dilutions of the primary antibodies varied between cryostat sections and the applied different fixation methods. Immunohistochemistry was performed with the Peroxidase anti-peroxidase (PAP) complex method. For the dilution of the antibodies and the PAP-complex, TBS containing $20 \%$ serum of a swine (pAb) and $1 \%$ bovine serum albumin $(\mathrm{mAb})$ was used. Sections of paraffin-embedded fixed (formalin, IHC Zinc Fixative, Hope ${ }^{\circledR}$ ) tissues were dewaxed and rehydrated. For blocking the endogenous peroxidase, a $0.5 \%$ hydrogen peroxide solution in methanol (cryostat sections, formalin and zinc fixation, $30 \mathrm{~min}$ at RT) or distilled water (Hope ${ }^{\circledR}, 10$ min at RT) was used. Antigen retrieval was performed only on formalin fixed tissue. Protease antigen retrieval was used for CD3-immunostaining: Slides were incubated in sodium phosphate buffer $\left(37^{\circ} \mathrm{C}\right.$, $5 \mathrm{~min}$ ) and then treated with a proteinase solution (bacterial proteinase, Sigma-Aldrich Chemie $\mathrm{GmbH}$, Taufkirchen, Germany, $0.5 \%$ in sodium phosphate buffer, $\left.37^{\circ} \mathrm{C}, 5 \mathrm{~min}\right)$; subsequently slides were rinsed in ice-cold TBS $(3 \times, 5 \mathrm{~min})$. To prevent non-specific binding of primary antibodies, sections were preincubated in $50 \%$ normal swine serum (anti-CD3 antibody) or $10 \%$ normal horse serum (anti-CD4 and anti-CD8 antibodies) for $10 \mathrm{~min}$ at RT. Primary antibodies were added and incubated overnight at $4^{\circ} \mathrm{C}$. Subsequently, slides were washed and incubated with swine anti-rabbit immunoglobulin $G$ (pAb: 1:100; Dianova, Hamburg, Germany) or rat anti-mouse immunoglobulin G (mAbs: 1:100; Dianova) for $30 \mathrm{~min}$ at RT. After rinsing again, slides were treated with rabbit-PAP (pAb: 1: 100, Dianova) or mouse-PAP (mAb: 1:500, Dianova) for $30 \mathrm{~min}$ at RT. Diaminobenzidine (Sigma-Aldrich Chemie $\mathrm{GmbH}$ ) was used as chromogen. Nuclei were counterstained with Papanicolaou solution (Merck KGaA, Darmstadt, Germany). Equine lymph node was used as a positive control for all primary antibodies and all applied immunoreactions. For each immunostained slide, a negative control was performed, i.e. the antibody detecting CD3 antigen was replaced by rabbit immune serum and the anti-CD4 and anti-CD8 antibodies were substituted by a nonrelated monoclonal mouse immunoglobulin $G$ antibody (Hirschberger 1987). In the negative controls, the same dilution as for the primary antibodies was used.

\section{Comparative analysis of routinely stained tissue sections}

The HE stained sections of formalin- and zinc-fixed endometrial tissue samples that were collected from the 9 Thoroughbred mares and the 21 -year-old German riding pony were analyzed in regard to their morphologic tissue preservation, the quality of the HE staining using the routine protocol and the presence of significant tissue artefacts.

\section{Comparative analysis of immunostained tissue sections}

The immunoreactivity of the different primary antibodies in cryostat sectioned and fixed (formalin, IHC Zinc Fixative, Hope $^{\circledR}$ ) and paraffin embedded tissue samples was compared. In the case of a positive immunostaining, the optimal concentration of the primary antibody for the immunoreactions in cryostat sectioned or fixed paraffin embedded tissue samples was determined. The objective of this comparative analysis was to reveal the fixation method that would be most suitable for combining a routine microscopic evaluation of equine endometrial biopsies with the immunohistochemical analysis of $T$ cell subpopulations.

\section{Semiquantitative evaluation of the immunoreactions}

The numbers of CD3 + T cells as well as their CD4 + and CD8 + subpopulations were evaluated semiquantitatively in serial sections of IHC Zinc fixed endometrial tissue samples of 2 mares without and 8 mares with endometritis. Within 5 randomly selected high dry magnification fields (400x, HPFs), $\mathrm{CD} 3+, \mathrm{CD} 4+$ and CD8 $+\mathrm{T}$ cells were counted separately within the surface and glandular epithelium, the stratum compactum and the stratum spongiosum.

\section{Results}

Animals

In regard to the adult Thoroughbred broodmares, 7 (Nos. $1-4,8,9$ ) were healthy on gynecological examination, 1 (No. $5)$ showed not further described clinical signs of genital tract disease, 1 (No. 6) had an urovagina, and in 1 mare (No. 7) bacteriological culture of an endometrial swab revealed a positive growth of beta-hemolytic Streptococci. Six of these mares (Nos. 1-4,8,9) were covered in 2012 and five (Nos. $1-3,8,9)$ had foaled in 2013.

Histopathological examination of endometrial biopsies according to Kenney and Doig (1986) and Schoon et al. (1992) and (1997)

The results of the histopathological evaluation of the routinely stained $(\mathrm{HE})$ endometrial tissue samples are summa- 

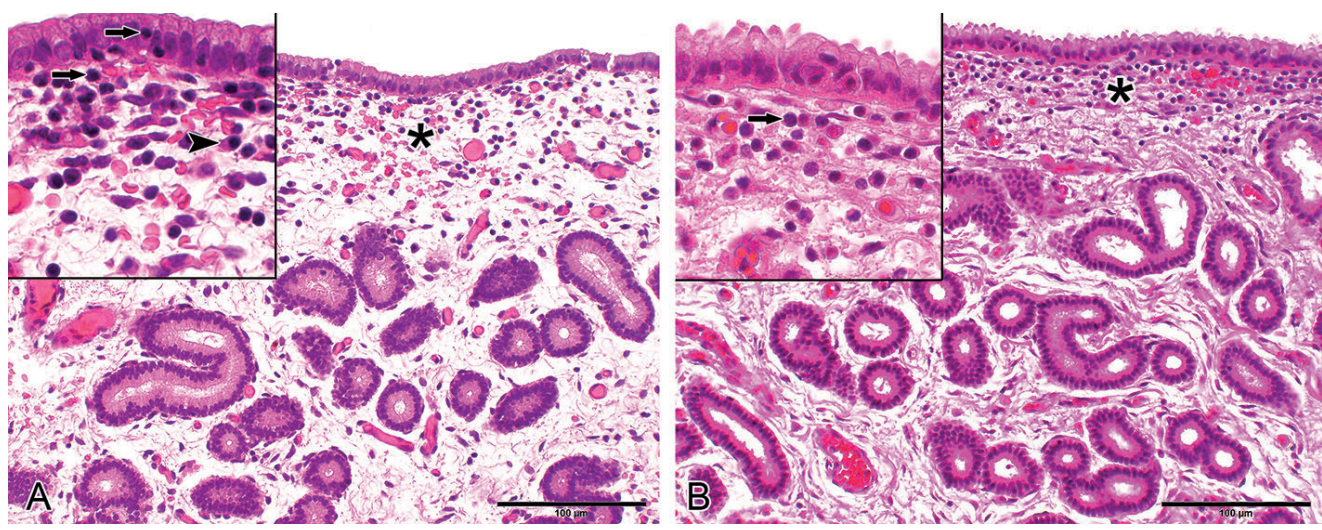

Fig. 1 Endometrial biopsies, mare No. 6, with a mild superficial non-suppurative endometritis, formalin-fixed (A) and IHC Zinc fixed (B), stained with haemalaun eosin. A comparable very good tissue preservation is observed with the formalin and zinc-fixation. IHC Zinc fixed endometrial tissue (B) has a slightly more eosinophillic tissue staining than the formalin fixed tissue (A) using an identical staining procedure. The superficial (asterisk: A, B) mild non-suppurative endometritis is characterized by a subepithelial infiltration with lymphocytes (arrows: A, B, insets) and plasma cells (arrowhead: A, inset). Scattered intraepithelial lymphocytes are noted (arrow: A, inset). Bar $=100 \mu \mathrm{m}$

Endometriumbioptate, Stute Nr. 6, mit einer geringgradigen oberflächlichen nicht-eitrigen Endometritis, Formalin fixiert (A) und IHC Zink fixiert (B), mittels Haemalaun und Eosin gefärbt. In der Formalin- und der Zink-Fixierung ist eine sehr gute Gewebserhaltung erkennbar. Unter Anwendung identischer Anfärbeverfahren zeigt IHC Zink fixiertes endometriales Gewebe (B) eine geringgradig eosinophilere Anfärbung als Formalin fixiertes Gewebe (A). Kennzeichnend für eine oberflächliche (Sternchen: A, B) geringgradige nicht-eitrige Endometritis ist eine subepitheliale Infiltration mit Lymphozyten (Pfeile: A, B, Insets) und Plasmazellen (Pfeilspitze: A, Inset). Vereinzelt konnten intraepitheliale Lymphozyten nachgewiesen werden (Pfeil: A, Inset). Messbalken $=100 \mu \mathrm{m}$.

Table 1 Histological evaluation of equine endometrial tissue samples according to Kenney and Doig (1986) and Schoon et al. (1992) and (1997) / Histologische Befunderhebung am equinen Endometrium nach Kenney und Doig (1986) und Schoon et al. (1992) und (1997)

\begin{tabular}{cccccc}
\hline Mares & Non-suppurative endometritis & Endometrosis & Angiosclerosis & Glandular functional morphology & Maldifferentiation \\
\hline 1 & - & - & + & - & proliferative \\
2 & - & - & ++ & secretory \\
3 & + & + & ++ & secretory \\
4 & + & + & + & proliferative \\
5 & + & + & ++ & proliferative \\
6 & + & + & - & proliferative \\
7 & + & + & ++ & secretory \\
8 & + & - & secretory & - \\
9 & + & ++ & ++ & secretory & - \\
10 & + & ++ & ++ & secretory & irregular \\
\hline
\end{tabular}

+ , mild; ++ , moderate, -, absent

Table 2 Analysis of the preservation of the equine endometrium in Haemalaun Eosin stained cryostat* sectioned or fixed (different three methods) paraffin embedded tissue samples / Untersuchungen bezüglich der Gewebsmorphologie am equinen Endometrium in HE gefärbten Gefrierschnitten* bzw. in fixiertem (drei verschiedene Methoden) Paraffin eingebetteten Material

\begin{tabular}{|c|c|c|c|c|}
\hline Criteria analysed & Frozen tissue & Hope ${ }^{\circledR}$ Fixation & IHC Zinc Fixative & Formalin-Fixation \\
\hline Tissue preservation & suboptimal & suboptimal & very good & excellent \\
\hline HE staining & excellent & excellent & excellent & excellent \\
\hline Artefacts & moderate** & mild $^{* * *}$ & not significant & not significante \\
\hline Use for routine diagnostics & suboptimal & sufficient & very good & excellent \\
\hline
\end{tabular}

${ }^{*}=$ native frozen tissue was used for cryostat sections, these were fixed in acetone $(10 \mathrm{~min})$ prior to immunostaining ${ }^{* *}=$ moderate tissue artefacts, i.e. clear clefts (ice crystal formation), multiple cell layers $\quad * * *=$ mild cleft formation $\quad H E=$ Haemalaun Eosin

Table 3 Immunohistochemical reactivity of antibodies for the detection of T lymphocytes in cryostat sectioned* and fixed (three different methods) paraffin embedded equine endometrial tissue samples / Immunhistochemische Reaktivität der Antikörper bezüglich des Nachweises von T-Lymphozyten in Gefrierschnitten* und in fixiertem (drei verschiedene Methoden) Paraffin eingebetteten Material des equinen Endometriums

\begin{tabular}{lccc}
\hline Tissues Treatment & CD3 - Reactivity & CD4 - Reactivity & CD8 - Reactivity \\
\hline Unfixed & +++ & +++ & +++ \\
HOPE ${ }^{\circledR}$ Fixative & +++ & +++ & ++ \\
IHC Zinc Fixative & +++ & - & +++ \\
Formalin-Fixation & +++ & - \\
\hline
\end{tabular}

* = native frozen tissue was used for cryostat sections, these were fixed in acetone (10 min) prior to immunostaining

- = non-reactive $;++$ strong immunohistochemical staining 
rized in table 1. Two mares (Nos. 1,2) did not show any microscopic evidence of endometritis or endometrosis. In the remaining 8 mares (Nos. 3-10) a superficial mild non-suppurative endometritis was diagnosed. The cellular infiltrate was restricted to the stratum compactum consistent with a superficial endometritis; it was composed of lymphocytes and fewer plasma cells (Fig. 1 A, B). Endometrosis was noted in 7 mares, it was mild in 5 mares (Nos. 3-7) and moderate in 2 mares (Nos. 9, 10). Angiosclerosis was observed in 8 mares, it was mild (Nos. 1,5) or moderate (Nos. $3,4,6,8-10)$. Two mares (Nos. 3,9) showed an irregular glandular differentiation; in the remaining mares uterine glands were regular proliferative (Nos. 1,4,5,6) or secretory (Nos. 2,7,8,10) differentiated.

\section{Tissue preservation in routinely stained tissue sections}

Table 2 summarizes the results of the comparative analysis of cryostat sectioned and fixed paraffin embedded (three different methods), endometrial tissue samples stained for the routine light microscopic examination. Formalin-fixed tissue samples showed excellent tissue preservation combined with excellent staining characteristics; no significant artefacts were observed (Fig. 1A). The tissue preservation in IHC Zinc fixed endometria was only slightly reduced as compared to the formalin-fixation, it was still evaluated as very good. Using an identical HE staining protocol, the HE stained sections of the IHC Zinc-fixed tissue appeared more eosinophilic than those of formalin-fixed tissue (Fig. $1 A, B)$. Thus, for comparative staining results with both fixation methods, the staining protocol would have to be modified slightly. Although tissues treated with the Hope ${ }^{\circledR}$ fixation had similar staining characteristics as formalin-fixed tissues, the tissue preservation was mildly to moderately reduced and therefore less optimal. In comparison, cryostat sections showed even moderately impaired tissue preservation, while their staining characteristics were very good. In addition, unfixed cryostat sections were slightly thicker than sections of fixed paraffin-embedded tissues and therefore less optimal for a routine microscopic examination due to the possible presence of overlapping cell layers. In summary, these findings show that - in addition to the formalin-fixation - only the IHC Zinc Fixative will result in an optimal tissue quality.

\section{Comparative analysis of immunostained tissue sections}

A comparison of the immunohistochemistry for the detection of T lymphocytes and their CD4+ and CD8+ subpopulations in cryostat sectioned and fixed (three different methods) paraffin embedded tissue is depicted in table 3. The immunhistochemistry for the detection of the pan-T cell marker CD3 can be performed on cryostat sectioned tissue samples and on endometrial tissues treated with each of the three different fixation methods followed by paraffin embedding. Antigen retrieval, however, is required for the CD3 immunostaining in formalin-fixed tissue. Using the Hope ${ }^{\circledR}$ and IHC Zinc fixed tissues (Fig. 2A) the anti-CD3 antibody can be applied in a higher dilution as on cryostat sectioned or formalin-fixed tissues. This study revealed that not only cryostat tissue sections, but also Hope ${ }^{\circledR}$ or $\mathrm{IHC}$ Zinc fixed,

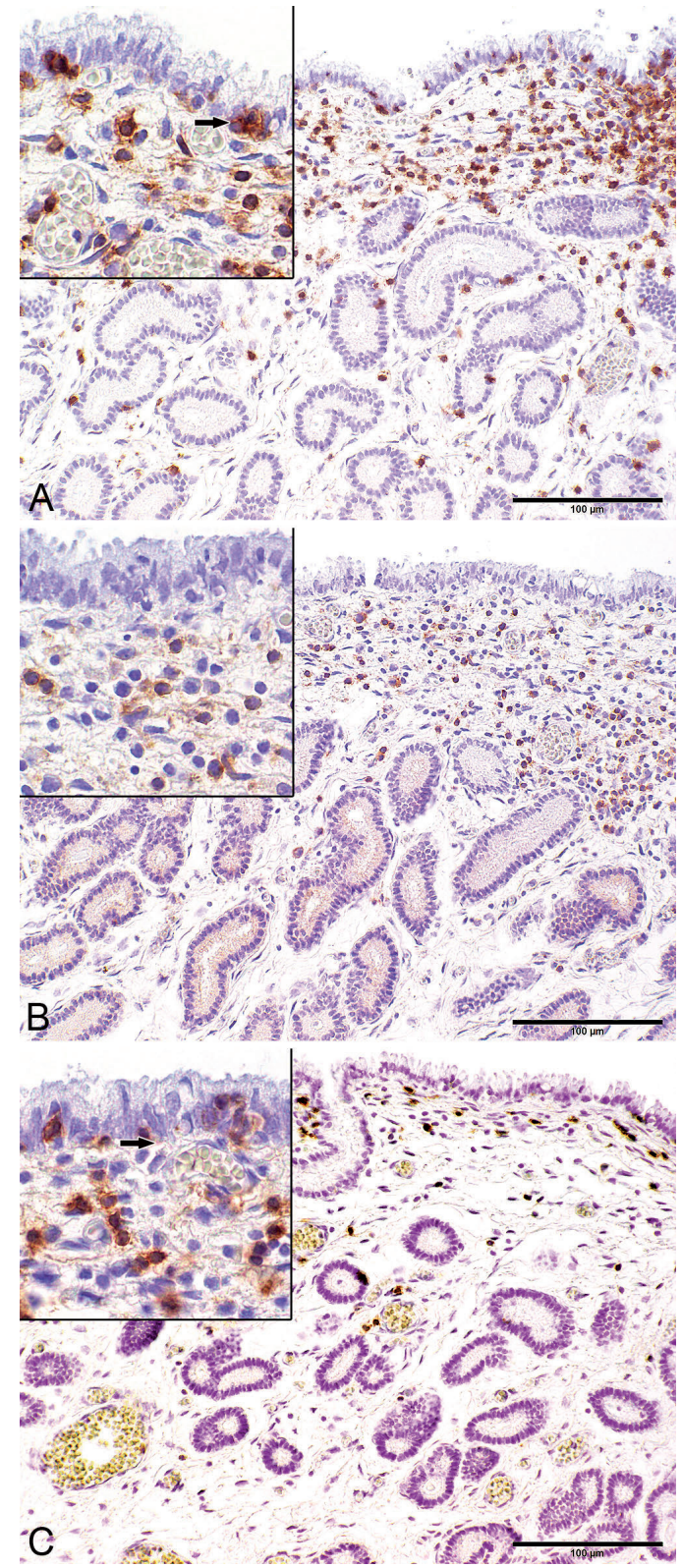

Fig. 2 Endometrial biopsies, mare No. 5, with a mild superficial non-suppurative endometritis, immunohistochemical detection of CD 3 antigen (A), CD4 antigen (B) and CD8 antigen (C) on zinc-salt fixed tissue samples. The mild superficial non-suppurative endometritis is associated with an increase of CD3-, CD4- and CD8-immunopositive cells within the stratum compactum (A-C). CD3- and CD8-immunopositive intraepithelial lymphocytes are observed $(A$, C). Mild numbers of CD3-, CD4- and CD8-immunopositive cells are also observed within the stratum spongiosum. In the insets, the immunolabelled cells within the stratum compactum and the luminal epithelium (arrow: A, C) are depicted at a higher magnification. Bar $=100 \mu \mathrm{m}$.

Endometriumbioptate, Stute Nr. 5, mit einer geringgradigen oberflächlichen nicht-eitrigen Endometritis, immunhistochemischer Nachweis von CD3 Antigen (A), CD4 Antigen (B) und CD8 Antigen (C) am Zinksalz fixierten Gewebe. In den Endometrien von Stuten mit einer geringgradigen oberflächlichen nicht-eitrigen Endometritis findet sich eine Zunahme von CD3-, CD4- und CD8-immunpositiven Zellen im Stratum compactum (A-C). CD3- und CD8-immunpositive Zellen sind intraepithelial nachweisbar (A, C). Eine geringe Anzahl an CD3-, CD4- und CD8-immunpositiven Zellen ist innerhalb des Stratum spongiosums nachweisbar. In den Insets sind die immunpositiven Zellen, die innerhalb des Stratum compactum sowie in dem luminalen Epithel (Pfeil: A, C) vorliegen, in einer höheren Vergrößerung dargestellt. Messbalken $=100 \mu \mathrm{m}$. 


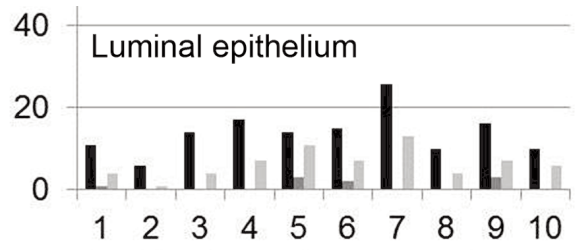

A Numbers of examined mares
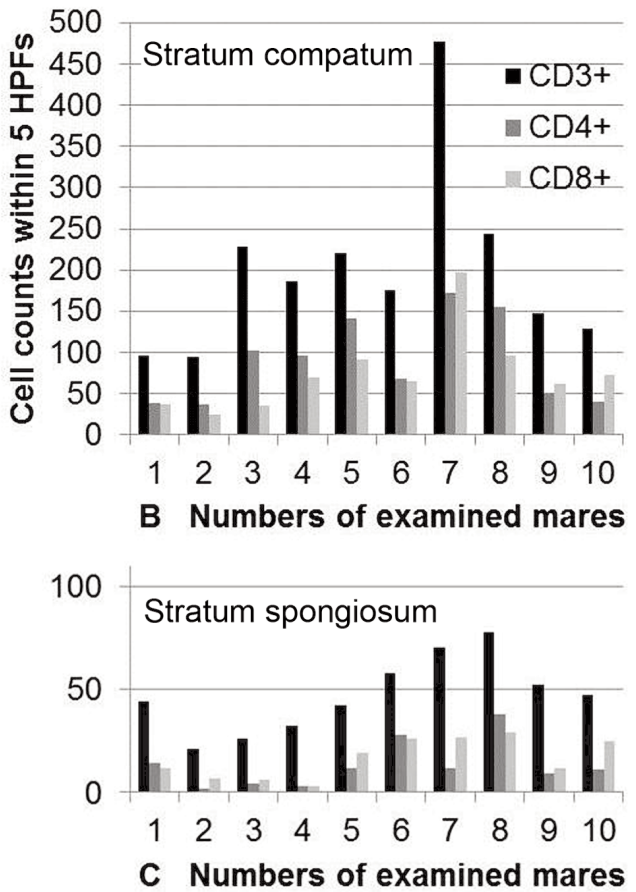

Fig. 3 Results of the semiquantitative analysis of CD3-, CD4- and CD8-immunopositive cells within the endometrium of 2 mares without (Nos. 1,2) and 7 mares with a mild superficial non-suppurative endometritis (Nos. 3-10). Average numbers of the immunolabelled cell populations were higher in mares with endometritis than in mares without endometritis. A. In the luminal epithelium of mares with and without endometritis, low numbers of CD3- and CD8-immunopositive cells and only very few CD4-immunopositive cells were observed; this indicates that the majority of intraepithelial lymphocytes are cytotoxic T cells. B. In the stratum compactum, mares with endometritis have higher numbers of CD3 positive cells, increased numbers of CD4 and CD8 positive cells (Nos. 4-10) or an increased numbers of only CD4 positive cells (No. 3). C. In the stratum spongiosum of mares with and without endometritis, low numbers of CD3-, CD4- and CD8-immunopositive cells were observed. Average numbers of the immunolabelled cell populations were higher in mares with endometritis than in mares without endometritis.

Ergebnisse der semiquantitaven Analyse von CD3-, CD4- und CD8-immunpositiven Zellen innerhalb des Endometriums von 2 Stuten ohne $(\mathrm{Nr} .1,2)$ und 7 Stuten mit einer geringgradigen oberflächlichen nicht-eitrigen Endometritis (Nr. 3-10). In Endometrien von Stuten mit Endometritis liegt eine höhere durchschnittliche Anzahl immunpositiver Zellen vor als in Endometrien von Stuten ohne Endometritis. A. Innerhalb des luminalen Epithels von Stuten ohne und mit Endometritis konnten wenige CD3- und CD8-immunpositive Zellen und nur sehr vereinzelt CD4-immunpositive Zellen nachgewiesen werden, dies deutet darauf hin, dass die Mehrheit intraepithelialer Zellen zytotoxische T-Zellen sind. B. Bei Stuten mit einer Endometritis, liegt innerhalb des Stratum compactums eine höhere Anzahl von CD3sowie eine höhere Anzahl von CD4- und CD8- (Nr. 4-10) oder nur CD4-immunpositiven Zellen (Nr. 3) vor. C. Innerhalb des Stratum spongiosum von Stuten mit und ohne Endometritis liegen CD3-, CD4- und CD8-immunpositive Zellen in einer geringen Anzahl vor. Jedoch ist die durchschnittliche Anzahl dieser immunpositiven Zellen höher bei Stuten mit Endometritis als bei Stuten ohne Endometritis. paraffin embedded tissue can be used for the immunohistochemical detection of CD4 + and CD8 + T cell subpopulations. Therefore, the IHC Zinc fixation provides not only good quality HE stained tissue sections, but also allows the immunohistochemical detection of CD4 and CD8 antigens (Fig. 2B,C).

\section{Semiquantitative evaluation of the immunoreactions}

The results of this analysis are provided in Figure 3. In regard to the evaluated endometrial locations, even in the 2 mares without endometritis (Nos. 1,2), higher numbers of lymphocytes were observed within the stratum compactum than within the stratum spongiosum. In all evaluated endometrial compartments (epithelium, stratum compactum, stratum spongiosum), higher numbers of CD3 + cells than CD4+ or $\mathrm{CD} 8+$ cells were detected indicating that most of the observed CD4+ and CD8+ cells were also CD3+.

Luminal and glandular epithelium

Mares without endometritis (Nos. 1,2) had lower average numbers of intraepithelial lymphocytes in the luminal epithelium ( 9 cells per 5 HPFs) as well as in the glandular epithelium (8 cells per $5 \mathrm{HPFs}$ ) than mares with endometritis (16 and 14 cells per 5 HPFs, respectively). The total counts of CD4 + and CD8 + cells were less than the total numbers of CD3 + T cells; only in the luminal epithelium of 1 mare (No. 5) total counts of CD4+ and CD8+ cells were equal to the total numbers of CD3 + T cells. In regard to the analyzed lymphocytic subpopulations, CD8 + cells predominated; CD4+ cells were scant and not observed in 1 mare (No. 2).

\section{Stratum compactum}

In mares without endometritis (Nos. 1,2) and a secretory (No. 2) or proliferative (No. 1) morphology of uterine glands, similar cell numbers of CD3 +, and CD4 + T cells were counted, whereas differences in the numbers of CD8+ cells were noted. In comparison, increased numbers of CD3 $+\mathrm{T}$ cells were observed within the stratum compactum of mares with a mild superficial non-suppurative endometritis. Six of these mares showed an increase in the numbers of CD4+ and CD8 + cells, in 1 mare (No. 3) only CD4 + cells were increased. The relative numbers of CD4+ and CD8+ T cells varied between individual mares ranging from $35 \%$ to $74 \%$ of CD4 + cells and from $26 \%$ to $65 \%$ of CD $8+$ cells; thus affected mares did neither show a predominance of an identical cell population (either CD4+ or CD8+ cells) nor an extremely high count of one of these two cell populations. Average total counts of CD4 + cells (103 cells per 5 HPFs) und CD8 + cells (86 cells per 5 HPFs) were slightly lower than the average of counted CD3 + cells (227 cells per 5 HPFs ).

\section{Stratum spongiosum}

Mean numbers of CD3,+ CD4 + and CD8 + T cells were slightly higher in mares with a superficial mild non-suppurative endometritis (CD3+: 51 per 5HPFs; CD4+: 15 per 5 
HPFs, CD8+: 18 per 5HPFs) than in mares without endometritis (CD3+: 33 per 5HPFs; CD4+: 8 per 5 HPFs, CD8+: 10 per 5HPFs), although differences between individual mares were observed. Within the same mare, only mild differences in the numbers CD4+ and CD8+ positive cells were noted (ranging from 2 - 9 cells); cell counts differing in more than 10 cells were observed in only 2 mares (Nos. 7, 10). In mares with endometritis, the stratum spongiosum contained lower numbers of CD3+, CD4+ and CD8+ lymphocytes than the stratum compactum consistent with a superficial non-suppurative endometritis.

\section{Discussion}

This study showed that in equine tissue, CD4 + and CD8 $+\mathrm{T}$ cell subpopulations can also be detected in fixed tissue samples (IHC Zinc and Hope ${ }^{\circledR}$-fixation). Furthermore, it revealed that the IHC Zinc Fixative is an excellent method to combine the routine histopathological evaluation of equine endometrial biopsies with the analysis of $\mathrm{T}$ cell supopulations in equine endometrial tissue. The investigation of endometrial tissue samples of mares with a mild superficial non-suppurative endometritis showed that CD4 + and CD8 + T cells contribute to the inflammatory cell infiltrate of this disease.

\section{Immunohistochemistry for the detection of CD4+ and CD8+} cells

To the best of the authors' knowledge, this is the first description of the successful immunohistochemical labelling of CD4 + and CD8 + T lymphocytes in fixed paraffin embedded equine endometrial tissue samples. Previous studies on the immunohistochemical detection of CD4+ and CD8+ lymphocytes in equine tissue including the corpus luteum (Lawler et al. 1999) and the equine endometrium (Watson and Thomson 1996, Tunón et al. 1999, Tunón et al. 2000) solely used cryostat sections of frozen native tissue that were briefly fixed in acetone prior to immunohistochemistry.

The routinely used formalin-fixation will impair the detection of CD4 and CD8 antigens, since the epitopes will be masked by methylol groups (French and Edsall 1945). That means that methylene bridges cross-link with amino groups and prevent the reaction of the epitope with the antibody (French and Edsall 1945). It is reported that a specific pretreatment (pressure cooking in an antigen retrieval solution containing $1 \mathrm{mM}$ EDTA, $1 \mathrm{mM} \mathrm{NaCL}$ and borate at $\mathrm{pH}$ 8) will result in the retrieval of CD4 and CD8 antigen in human lymphoid tissue (Kim et al. 2004). To the authors' knowledge, the use of this method has not been published in veterinary medicine. In regard to the Zinc salt fixative, Beckstead (1994) demonstrated that zinc-salt fixation of lymphoid tissue not only retained antigenicity for the detection of CD4+ and CD8+ as well as additional lymphocyte markers, but also showed good morphologic tissue preservation. In addition, zinc fixation was used on ovine lymph node (González et al. 2001) and murine lymphatic organs and additional tissues (Hicks et al. 2006) for the detection of different immune cell epitopes including CD4 and CD8.

The method of Hope ${ }^{\circledR}$-fixation (Hepes-Glutamic acid buffer mediated Organic solvent Protection Effect) was first pub- lished by Olert et al. (2001) for the use on human soft tissue. In contrast to the formalin-fixation, this method lacks protein crosslinking of epitopes and significant degradation of nucleic acids (Olert et al. 2001). The Hope ${ }^{\circledR}$ fixation has been applied in human (Droemann et al. 2003) and veterinary medicine (Hornickel et al. 2011) for the immunohistochemical detection of different antigens. It was also used for molecular studies (Witchell et al. 2008).

Comparison of the investigated methods for the detection of lymphocytes in equine endometrial biopsies

The present investigation showed that the zinc-salt fixation is superior to the Hope ${ }^{\circledR}$ fixation and the use of cryostat sectioned tissue samples (frozen tissue, briefly fixed in acetone prior to HE staining and immunohistochemistry), since it allows not only the immunohistochemical detection of CD4 and CD8 antigens, but is also associated with a good morphologic tissue preservation. Further advantages of the zinc-salt fixation are 1) the relatively low costs, 2) the possibility to place the endometrial biopsy immediately after its collection in a ready to use fixative, 3) the lack of specific requirements for the transport of the fixed endometrial biopsy to the diagnostic laboratory as well as 4) the possibility to store paraffin-blocks of zinc-fixed tissue at RT. As per manufacturers' instructions, the fixation time should not exceed $48 \mathrm{hrs}$. Endometrial biopsies, however, are usually submitted within $24 \mathrm{hrs}$ to the diagnostic laboratory, since commonly a fast diagnosis is required to allow specific treatment.

In comparison, the use of frozen tissue for cryostat sections or the Hope ${ }^{\circledR}$-fixation is less practical to perform, in particular if a spatial distance between the biopsy collection site (stud farm, stable) and the diagnostic laboratory exist. Unfixed tissue samples have to be shock-frozen immediately after their collection and stored frozen until their use. The Hope ${ }^{\circledR}$-fixation is relatively work intensive, since it requires different fixation steps with specific temperature requirements.

The use of frozen tissue samples or Hope ${ }^{\circledR}$ fixed tissues has disadvantages for a routine diagnostic laboratory. Both types of samples cannot be stored at room temperature. For the handling of unfixed tissues and paraffin-blocks of Hope ${ }^{\circledR}$-fixed tissues, special precautions are recommended, since pathogens may not be inactivated.

Thus, the zinc-salt fixation is an excellent alternative fixation method, that has even some advantages compared to the formalin-fixation, i.e. antigen retrieval is not required, a higher dilution of the primary antibody may be sufficient saving costs, and it will allow the immunohistochemical detection of antigens that are masked by formalin.

\section{Histopathological examination of endometrial biopsies}

In all examined endometrial samples, lymphocytes were observed within the luminal and glandular epithelium and the stratum spongiosum, whereas lymphocytes and fewer plasma cells were present within the stratum compactum. Inflammation of the equine endometrium is defined as the presence of a higher numbers of inflammatory cells than those commonly 
observed during the oestrus cycle (Brunckhorst et al. 1991, Schoon et al. 1992). The present study focused selectively on the further characterisation of the observed T cells.

Immunohistochemical analysis of $T$ cells including their subpopulations

The CD3 molecule forms a complex with the T cell receptor (Groh et al. 1989); therefore it represents a pan-T cell marker labelling mature non-neoplastic $T$ cells (Blanchard-Channell et al. 1994). It has been shown that in equine lymphocytes the presence of CD4 and CD8 antigens is mutually exclusive (Kydd et al. 1994). In the present case, the morphologic features of the CD4 and CD8 immunolabelled cells were consistent with lymphocytes. The numbers of CD3 + cells, however, were often slightly higher than the total counts of CD4 + and CD8 + cells. This may be explained by differences in cell numbers in the counted areas, since serial sections were analysed. The presence of CD3+ CD4- and CD8-double negative lymphocytes, however, cannot be ruled out (Watson et al. 1997, Patton et al. 2004, D'Acquisto and Crompton 2011). It is reported that in human and mouse genital tissue CD3 + CD4- and CD8double negative lymphocytes can even approach 70-90\% of the lymphocytic population ( $D^{\prime}$ Acquisto and Crompton 2011 ). There is evidence that this lymphocyte subclass can either acquire an immunomodulatory function or can promote inflammation, also in the context of autoimmune mediated disease; factors that promote one or the other phenotype have to be still characterized ( $D^{\prime}$ Acquisto and Crompton 2011). The detected CD8 cells likely represent cytotoxic $T$ cells of the adaptive immunity. The applied anti-equine CD8 antibody recognizes a peptide chain of CD8 ( $\beta$-chain) that is not present in CD8 $+\mathrm{T}$ cells of the immediate immune defence ( $\gamma \delta \mathrm{T}$ cells, Kydd et al. 1994). This cell population is linked to immediate cellular immune defence (Murphy et al. 2009) and has been identified in the bovine endometrium (Oliveira et al. 2013). In addition to the presence of $\mathrm{CD} 4+\mathrm{TH} 1$ and/or $\mathrm{TH} 2$ cells; Tregs and TH1 7 may contribute to the observed CD4 + cell population. Tregs have been identified in the human endometrium (Berbic et al. 2010) and in the equine pregnant endometrium (de Mestre et al. 2010).

To definitively characterize the CD3 and/or CD4 or CD8 antigen expressing $T$ cell populations of the healthy and diseased equine endomerium, double labelling for these antigens in addition to the identification of further $T$ cell lineage specific antigens would be required.

$T$ cell subpopulations in the equine endometrium with and without inflammation

Interestingly, the present study revealed that the vast majority of intraepithelial T lymphocytes in mares with and without endometritis were $\mathrm{CD} 8+$. A predominance of CD8+lymphocytes was also observed in the human endometrium (Pace et al. 1991) and excurrent ducts of the human testis (Yakirevich et al. 2002). In the latter investigation, the authors speculate that intraepithelial leucocytes may hinder the development of immune reactions against sperm antigen (Yakirevich et al.
2002). Interestingly, in horses sperm is deposited directly into the uterine lumen (Sendel 2010).

In an investigation on 32 gynecologically healthy oestrous mares without cytologic or microscopic evidence of endometritis, Tunón et al. (1999) did not observe an influence of age or parity on the numbers of CD4 + and CD8 + T cells within the stratum compactum. Similar to the results of previous studies (Watson and Dixon 1993, Watson and Thomson 1996) on genitally healthy mares, this investigation showed the presence of higher numbers of $T$ cells, including their CD4 + and CD8+ subpopulations, within the stratum compactum than within the stratum spongiosum. Nearly equal numbers of CD4+ and CD8 + cells were detected within the human endometrial stroma of women with regular cycle (Bonatz et al. 1992). In contrast, in the bovine endometrium higher numbers of CD4 + than CD8 + lymphocytes were observed (Cobb and Watson 1995, Oliveira et al. 2013).

To the best of the authors' knowledge, there are no publications regarding the subpopulations of T lymphocytes observed in horses with endometritis including those with the non-suppurative form. In this study, the relative numbers of CD4 + and CD8 + T cells between individual mares with endometritis varied slightly, an excessively high count of one of these two cell populations, however, was not detected. These findings might be explained by an unequal distribution of these cell populations within the evaluated areas, individual variations of the immune response to particular antigens, differences in regard to the pathogenesis of the endometritis (differences in regard to the initiating cause or the time duration since tissue exposure) and/or an influence of the immune cell population by the presence of concurrent endometrial disease such as endometrosis and/or angiosclerosis. Notably, Tunón et al. (2000) observed a selective increase of CD4 + lymphocytes in the uterine body of mares after insemination that occurred within $6 \mathrm{hrs}$. In the literature, however, the presence of an endometrial inflammation with mononuclear cells is commonly considered as a chronic condition (Kenney and Doig 1986). Further investigations appear necessary to analyze the recruitment time for mononuclear cell populations in the equine endometrium. Interestingly, studies on human chronic endometritis as well as unexplained infertility results showed also an increased number of only CD4+ cells (Klentzeris et al. 1994, Matteo et al. 2009).

\section{Conclusion}

Results of this study suggest that a complex interaction of immune cells contributes to the maintenance of endometrial health and the development of a non-suppurative endometritis, an endometrial disease with economic significance. To detect the aetiology/aetiologies of this inflammatory condition and to develop specific treatment strategies, further comparative investigations into immune defences of the healthy and diseased equine endometrium are necessary. For this purpose, the described zinc-salt fixation method appears to be a powerful diagnostic tool, since it allows to combine the routine microscopic evaluation of endometrial biopsies with the immunohistological characterisation of antigens that may be masked by the routinely used formalin-fixation. 


\section{Acknowledgement}

The authors thank Ms Wipplinger and the histology laboratory, Institute of Veterinary-Pathology, University of Leipzig for excellent technical support.

\section{References}

Beckstead J. H. (1994) A simple technique for preservation of fixation-sensitive antigens in paraffin-embedded tissues. J. Histochem. Cytochem. 42, $1127-1134$

Berbic M., Hey-Cunningham A. J., Ng C., Tokushige N., Ganewatta S., Markham R., Russell P., Fraser I. S. (2010) The role of Foxp3+ regulatory T-cells in endometriosis: a potential controlling mechanism for a complex, chronic immunological condition. Hum. Reprod. 25, 900-907

Blanchard-Channell M., Moore P. F., Stott J. L. (1994) Characterization of monoclonal antibodies specific for equine homologues of CD3 and CD5. Immunology 82, 548-554

Bonatz G., Hansmann M. L., Buchholz F., Mettler L., Radzun H. J., Semm K. (1992) Macrophage- and lymphocyte-subtypes in the endometrium during different phases of the ovarian cycle. Int. J. Gynaecol. Obstet. 37, 29-36

Brunckhorst D., Schoon H.-A., Bader H., Sieme H. (1991) Morphologische enzym- und immunhistochemische Charakteristika des endometrialen Zyklus bei der Stute. Fertilität 7, 44-51

Burzyn D., Benoist C., Mathis D. (2013) Regulatory T cells in nonlymphoid tissues. Nat. Immunol. 14, 1007-1013

Cobb S. P., Watson E. D. (1995) Immunohistochemical study of immune cells in the bovine endometrium at different stages of the oestrous cycle. Res. Vet. Sci. 59, 238-41

D'Acquisto F., Crompton T. (2011) CD3 + CD4-CD8- (double negative) T cells: saviours or villains of the immune response? Biochem. Pharmacol. 82, 333-340

De Mestre A., Noronha L., Wagner B., Antczak D. F. (2010) Split immunological tolerance to trophoblast. Int. J. Dev. Biol. 54, 445-455

Droemann D., Goldmann T., Branscheid D., Clark R., Dalhoff K., Zabel P., Vollmer E. (2003) Toll-like receptor 2 is expressed by alveolar epithelial cells type II and macrophages in the human lung. Histochem. Cell Biol. 119, 103-108

French D., Edsall J. T. (1945) The reactions of formaldehyde with amino acids and proteins. Adv. Protein Chem. 2, 277-335

González L., Anderson I., Deane D., Summers C., Buxton D. (2001) Detection of immune system cells in paraffin wax-embedded ovine tissues. J. Comp. Pathol. 125, 41-47

Groh V., Porcelli S., Fabbi M., Lanier L. L., Picker L. J., Anderson T., Warnke R. A., Bhan A. K., Strominger J. L., Brenner M. B. (1989) Human lymphocytes bearing $T$ cell receptor gamma/delta are phenotypically diverse and evenly distributed throughout the lymphoid system. J. Exp. Med. 169, 1277-1294

Hicks D. J., Johnson L., Mitchell S. M., Gough J., Cooley W. A., La Ragione R. M., Spencer Y. I., Wangoo A. (2006) Evaluation of zinc salt based fixatives for preserving antigenic determinants for immunohistochemical demonstration of murine immune system cell markers. Biotech. Histochem. 81, 23-30

Hirschberger J. (1987) [Development and characterization of monoclonal antibodies against chicken Tlymphocytes.][in German]. Inaugural Dissertation, Faculty of Veterinary Medicine, Justus-Liebig-University, Giessen, Germany

Hornickel I. N., Kacza J., Schnapper A., Beyerbach M., Schoennagel B., Seeger J., Meyer W. (2011) Demonstration of substances of innate immunity in the esophageal epithelium of domesticated mammals. Part I-Methods and evaluation of comparative fixation. Acta Histochem. 113,163-174

Kenney R. M., Doig P. A. (1986) Equine endometrial biopsy. In: Morrow DA, editor. Current therapy in Theriogenology. 2nd ed. Philadelphia: WB Saunders; p. 723-729

Kidd P. (2003) Th1/Th2 balance: the hypothesis, its limitations, and implications for health and disease. Altern Med Rev. 8, 223-246

Kim S. H., Kook M. C., Song H. G. (2004) Optimal conditions for the retrieval of CD4 and CD8 antigens in formalin-fixed, paraffinembedded tissues. J. Mol. Histol. 35, 403-408

Klentzeris L. D., Bulmer J. N., Warren M. A., Morrison L., Li T. C., Cooke I. D. (1994) Lymphoid tissue in the endometrium of women with unexplained infertility: morphometric and immunohistochemical aspects. Hum. Reprod. 9, 646-652

Kydd J., Antczak D. F., Allen W. R., Barbis D., Butcher G., Davis W., Duffus W. P., Edington N., Grünig G., Holmes M. A., Lunn D. P., McCulloch J., O'Brien A., Perryman L. E., Tavernor A., Williamson S., Zhang C. (1994) Report of the First International Workshop on Equine Leucocyte Antigens, Cambridge, UK, July 1991. Vet. Immunol. Immunopathol. 42, 3-60

Lawler D. F., Hopkins J., Watson E. D. (1999) Immune cell populations in the equine corpus luteum throughout the oestrous cycle and early pregnancy: an immunohistochemical and flow cytometric study. J. Reprod. Fertil. 117, 281-290

LeBlanc M. M., Causey R. C. (2009) Clinical and subclinical endometritis in the mare: both threats to fertility. Reprod. Domest. Anim. 44, 10-22

Matteo M., Cicinelli E., Greco P., Massenzio F., Baldini D., Falagario T., Rosenberg P., Castellana L., Specchia G., Liso A. (2009) Abnormal pattern of lymphocyte subpopulations in the endometrium of infertile women with chronic endometritis. Am. J. Reprod. Immunol. 61, 322-329

Murphy K., Travers P., Walport M. (2009) Janeway Immunologie, Spektrum Akademischer Verlag, Heidelberg, 7th ed., p. 1109 1093

Olert J., Wiedorn K. H., Goldmann T., Kühl H., Mehraein Y., Scherthan H., Niketeghad F., Vollmer E., Müller A. M., Müller-Navia J. (2001) HOPE fixation: a novel fixing method and paraffin-embedding technique for human soft tissues. Pathol. Res. Pract. 197, 823-826

Oliveira L. J., Mansourri-Attia N., Fahey A. G., Browne J., Forde N., Roche J. F., Lonergan P., Fair T. (2013) Characterization of the Th Profile of the Bovine Endometrium during the Oestrous Cycle and Early Pregnancy. PLoS One 8, e75571

Pace D., Longfellow M., Bulmer J. N. (1991) Characterization of intraepithelial lymphocytes in human endometrium. J. Reprod. Fertil. 91, 165-174

Patton K. M., McGuire T. C., Fraser D. G., Hines S. A. (2004) Rhodococcus equi-infected macrophages are recognized and killed by CD8 + T lymphocytes in a major histocompatibility complex class I-unrestricted fashion. Infect. Immun. 72, 7073-7083

Schoon H.-A., Schoon D., Klug E. (1992) Uterusbiopsien als Hilfsmittel für Diagnose und Prognose von Fertilitätsstörungen der Stute. Pferdeheilkunde 8, 355-362

Schoon H.-A., Schoon D., Klug E. (1997) Die Endometriumbiopsie bei der Stute im klinisch-gynäkologischen Kontext. Pferdeheilkunde 13, 453-464

Sendel T. (2010) Anatomy, physiology and reproduction in the mare. Omafra Factsheet. 1-4

Sundrud M. S., Trivigno C. (2013) Identity crisis of Th 17 cells: Many forms, many functions, many questions. Semin. Immunol. 25, 263-272

Tunón A.-M., Katila T., Magnusson U., Nummijärvi A., RodriguezMartinez H. (2000) T-cell distribution in two different segments of the equine endometrium 6 and 48 hours after insemination. Theriogenology. 54, 835-841

Tunón A.-M., Rodríguez-Martínez H., Nummiiärvi A., Magnusson U. (1999) Influence of age and parity on the distribution of cells expressing major histocompatibility complex class II, CD4, or CD8 molecules in the endometrium of mares during estrus. Am. J. Vet. Res. 60, 1531-1535

Watson E. D., Dixon C. E. (1993) An immunohistological study of MHC class II expression and T lymphocytes in the endometrium of the mare. Equine Vet. J. 25, 120-124

Watson E. D., Thomson S. R. (1996) Lymphocyte subsets in the endometrium of genitally normal mares and mares susceptible to endometritis. Equine Vet. J. 28, 106-110

Watson J. L., Stott J. L., Blanchard M. T., Lavoie J. P., Wilson W. D., Gershwin L. J., Wilson D. W. (1997) Phenotypic characterization of lymphocyte subpopulations in horses affected with chronic obstructive pulmonary disease and in normal controls. Vet. Pathol. 34, 108-1 16

Witchell J., Varshney D., Gaijar T., Wangoo A., Goyal M. (2008) 
RNA isolation and quantitative PCR from HOPE- and formalinfixed bovine lymph node tissues. Pathol. Res. Pract. 204,105-111

Yakirevich E., Yanai O., Sova Y., Sabo E., Stein A., Hiss J., Resnick M. B. (2002) Cytotoxic phenotype of intra-epithelial lymphocytes in normal and cryptorchid human testicular excurrent ducts. Hum. Reprod. 17, 275-283

\section{Zusammenfassung}

Die Klassifizierung von Lymphozytensubpopulationen im equinen Endometrium könnte Antworten auf Fragen nach den endometrialen Immunabwehrmechanismen und die Pathogenese von nicht-eitrigen Endometritiden geben. In routinemäßig Formalin-fixiertem Material konnten bislang CD4- und CD8Antigene von T-Helferzellen bzw. zytotoxischen T-Zellen nicht nachgewiesen werden. Für den immunhistochemischen Nachweis CD4- und CD8-immunpositiver Zellen im equinen Endometrium wurden deshalb Gefrierschnitte verwendet. Das Ziel dieser Studie war 1) alternative Fixierungsmöglichkeiten für den immunhistochemischen Nachweis von CD4- und CD8-immunpositiven Zellen zu finden, 2) eine optimale Methode sowohl für die mikroskopische Befunderhebung als auch für die immunhistochemische Charakterisierung von Lymphozyten zu etablieren, und 3) die Verteilung CD4- und CD8-immunpositiver Lymphozyten im Endometrium mit und ohne nicht-eitriger Endometritis zu untersuchen. Mittels Zinksalz- und Hope ${ }^{\circledR}$-Fixierung, als alternative Fixierungsmethoden, war es möglich, CD4- und CD8-immunpositive Lymphozyten im equinen Endometrium durch immunhistochemische Verfahren nachzuweisen. Die Zinksalzfixierung zeigte die besten Ergebnisse bezüglich der Struktur- erhaltung an Haemalaun-Eosin gefärbten Paraffinschnitten; diese war vergleichbar mit der von Formalin-fixiertem Material. Die immunhistochemische Untersuchung von endometrialem Gewebe zweier Stuten ohne Endometritis und von sieben Stuten mit einer geringgradigen oberflächlichen nicht-eitrigen Endometritis zeigte das Vorliegen von CD4- und CD8-immunpositiven Lymphozyten im Stratum compactum sowie im Stratum spongiosum. Im geringgradig nicht-eitrig entzündeten Endometrium lag eine erhöhte Anzahl von CD4- und CD8-immunpositiven Lymphozyten im Stratum compactum vor. Es wurde nachgewiesen, dass 1) Subpopulationen von T-Lymphozyten (CD4 und CD8) auch in fixiertem Material (IHC Zinc Fixative und Hope ${ }^{\circledR}$-Fixierung) identifiziert werden können, 2) die Zinksalzfixierung die Methode der Wahl ist, wenn an fixiertem Material sowohl eine histopathologische Auswertung als auch eine Charakterisierung von T-Zellen durchgeführt werden soll, 3) das equine Endometrium mit einer adaptiven Immunabwehr ausgestattet ist, die die Bekämpfung extra- sowie intrazellulärer Erreger ermöglicht und 4) eine nicht-eitrige Endometritis mit einer Zunahme beider T-Zellsubpopulationen einhergeht, welche auf eine immunvermittelte Pathogenese hinweist. Weitere Untersuchungen bezüglich der Charakterisierung der Lymphozytenpopulationen im equinen Endometrium unter physiologischen und pathologischen Bedingungen sind nötig. Die hier beschriebene Methode eignet sich hervorragend für diagnostische und wissenschaftliche Zwecke.

Schlüsselwörter: CD4-Antigen / CD8-Antigen / Endometritis / Stute / T-Lymphozytensubpopulationen / Zinksalzfixierung / Reproduktion 